\title{
EFFECTIVENESS OF PEER TUTORING TECHNIQUE ON ACHIEVEMENT OF STUDENTS IN GENERAL SCIENCE THROUGH ENGLISH AS MEDIUM INSTRUCTION AT HIGH SCHOOL LEVEL
}

\author{
W. GLADYS COLCRAFT ${ }^{1} \&$ Dr. P. RAJASEKAR ${ }^{2}$ \\ ${ }^{I}$ Research Scholar, School of Education, Ponnaaiyah Ramajayam Institute of Science and Technology, \\ Thanjavur, Tamil Nadu, India \\ ${ }^{2}$ Dean and Professor, School of Education, Ponnaaiyah Ramajayam Institute of Science and Technology,
}

Thanjavur, Tamil Nadu, India

\begin{abstract}
In the Education parlance language plays a multiple role to enhance learning outcome to establish to spatial and temporal relationship in terms of Sociology, Psychology, Culture Science, Technology and Literature. In the changing scenario, English becomes handy to put across the content of the subjects like General Science in the class room to the learners, when it is being used as a second language.

KEYWORDS: Activity Based Learning, Peer Tutoring, Effectiveness, Achievement, General Science, High School Level, English Language Across the Curriculum \& Medium of Instruction
\end{abstract}

Received: May 01, 2019; Accepted: May 22, 2019; Published: Jun 17, 2019; Paper Id.: IJCMSAUG20193

\section{INTRODUCTION}

When the peer tutoring technique is practiced in a class -room the practioner should bear in mind, the type of language to be utilized for this technique. This makes the learners acquire Listening, Speaking, Reading and Writing skills and explore new concepts and ideas in the subject. This will enable the students to improve their language proficiency across the curriculum.

\section{Role of English in India}

The role and importance of English language in Modern India cannot be denied. India has been moving towards progress in this age of Science and Technology. Many of the books on higher study on Science, Technology, Medicine, Engineering etc are written in English. knowledge of English promotes the specialized study of literature and philosophy. One can make a sojourn in the different branches of knowledge of the world.

\section{Position of English as Second Language in India}

In learning the mother tongue the child makes many mistakes in the beginning but these mistakes will disappear as the child grows up, But this automatic correction of errors can take place only when the learner keep using the language.

In the case of a second language, it happens to be a foreign language like English the natural sources are not available to the learner. Unlike the mother tongue a second language can be learnt deliberately i.e usually in a 
formal classroom. Therefore the classroom activity must provide significant motivation and scope for practicing the language.

\section{Peer Tutoring Defined Basically, It is a Man to Man Technique}

Peer tutoring facilities relevance, clarity coherence and organization. The technique provides the platform for the students solving problems themselves through interaction between high performer and low achiever. They work as a pair and focus their attention on the consent and the concept towards academic enhancement.

\section{OBJECTIVE OF THE STUDY}

The rational behind the Peer tutoring technique is that students can communicate and put across hard concepts easily without much strain and stress to their counter parts. Secondly language skills such as Listening, Speaking, Reading and Writing can be facilitated in all subjects across the curriculum.

\section{Hypothesis 1}

There is no significant difference in the pre test achievement level in the Experimental group which is exposed to the developed peer tutoring technique and the Control Group which is taught through the 'Conventional Black' board method in respect of "General Science" through English Language relating to High School Level.

\section{Comparison between Control Group and Experimental Group of the Mean Scores of Pre Test Achievement for the Subject General Science}

Table 1: Showing the Mean, Standard Deviation and ' $t$-Test' value of achievement of the student in General science between the Experimental group which is exposed to the developed Peer Tutoring Technique and the Control Group which is taught through the 'Conventional Black' board method in respect of “ General Science” through English Language relating to high School pre-test level.

Table 1

\begin{tabular}{|c|l|c|c|c|c|}
\hline Variable & \multicolumn{1}{|c|}{ Group } & N & Mean & Standard Deviation & 't' - Test Value \\
\hline GENERL & Experimental Group & 40 & 36.98 & 4.37 & \multirow{2}{*}{$\mathbf{0 . 0 0 1}$} \\
\cline { 2 - 5 } SCIENCE & Control Group & 40 & 15.25 & 3.07 & \multirow{2}{*}{} \\
\hline
\end{tabular}

Not significant at 0.05 level.

The calculated t- value 0.001 is less than the table value therefore, it is concluded that the Control group and the Experimental group do not differ in the Pre test achievement level.

The table value of ' $t$ ' at 0.05 level of significant is 1.96 . 


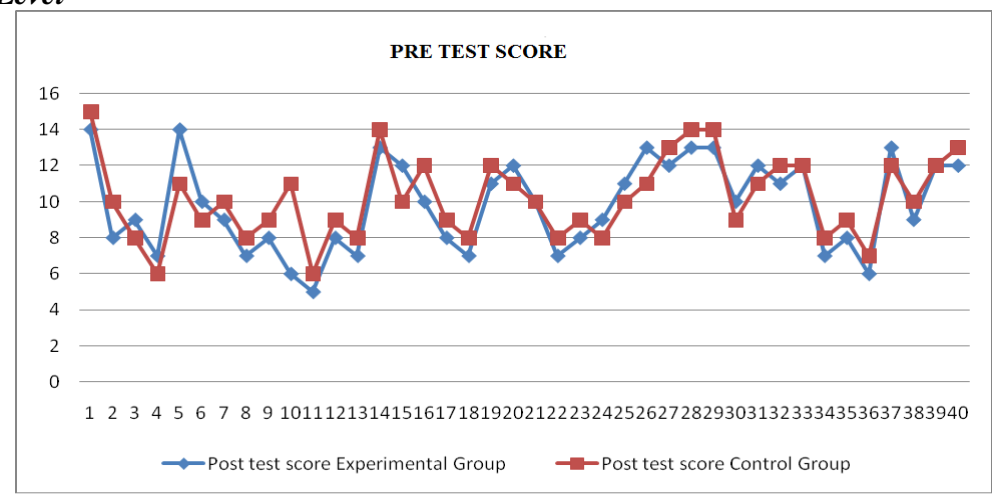

Figure 1: Pre Test Score

\section{Hypothesis 2}

There is no significant difference in the post test achievement at the students, in General Science the Experimental group which is exposed language to the developed peer tutoring technique and the Control Group which is taught through the conventional Black board method in respect of "General Science" through English Language relating to the High School Students in the post test level.

\section{Comparison between Control Group and Experimental Group of the Mean} Scores of Post-Test Achievement for the Topic General Science

Table 2: Showing the Mean, Standard Deviation and ' $t$-Test' value achievement at the students, in General Science the Experimental group which is exposed language to the developed peer tutoring technique and the Control Group which is taught through the conventional Black board method in respect of "General Science" through English Language relating to the High School Students in the post test level.

Table 2

\begin{tabular}{|c|l|c|c|c|c|}
\hline Variable & \multicolumn{1}{|c|}{ Group } & N & Mean & $\begin{array}{c}\text { Standard } \\
\text { Deviation }\end{array}$ & 't' - Test Value \\
\hline GENERAL & Experimental Group & 40 & 10.21 & 2.205 & \multirow{2}{*}{$\mathbf{0 . 0 9 5}$} \\
\cline { 2 - 5 } SCIENCE & Control Group & 40 & 9.83 & 2.479 & \\
\hline
\end{tabular}

Significant at 0.05 level.

It is inferred that the calculated ' $t$ ' of 0.095 is more than the table value. so it is concluded that the control Group differs with the Experiment.

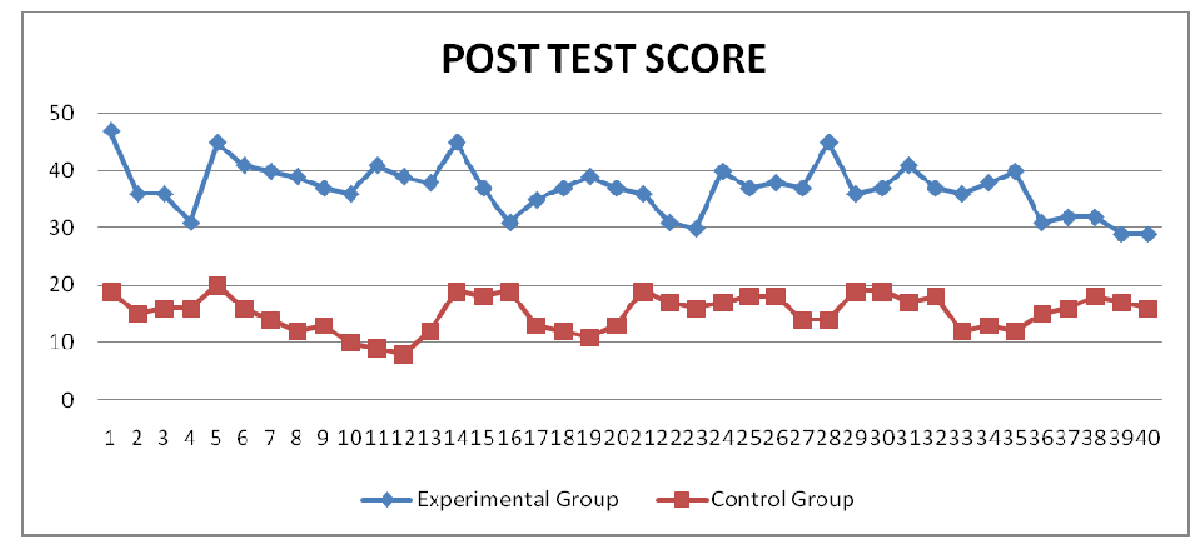

Figure 2: Post Test Score 


\section{Hypothesis 3}

There is no significant relationship in the post test achievement of the students High 'General Science' of the Experimental Group which is exposed to the developed Peer Tutoring Technique relating to High School Level on their attitude towards English at the Second Language.

\section{Correlation between Experimental Group of the Mean Score of Pre-Test} Achievement for the Subject General Science at High School Level

Table 3: Showing the Mean, Standard Deviation and Correlation ' $r$ ' value of the achievement of the students High 'General Science' of the Experimental Group which is exposed to the developed peer tutoring technique relating to high school level on their attitude towards information and communication technology.

Table 3

\begin{tabular}{|l|l|c|c|c|c|}
\hline \multicolumn{1}{|c|}{ Variable } & \multicolumn{1}{|c|}{ Group } & N & Mean & $\begin{array}{c}\text { Standard } \\
\text { Deviation }\end{array}$ & $\begin{array}{c}\text { Correlation } \\
\text { "r" value }\end{array}$ \\
\hline \multirow{2}{*}{$\begin{array}{c}\text { Experimental } \\
\text { Group }\end{array}$} & Post Achievement Test & 40 & 9.65 & 2.836 & \multirow{2}{*}{$\mathbf{0 . 1 6}$} \\
\cline { 2 - 5 } & $\begin{array}{l}\text { Attitude towards English } \\
\text { as Second Language }\end{array}$ & 40 & 156.88 & 17.69 & \multirow{2}{*}{} \\
\hline
\end{tabular}

If correlation $r=0.16$, It is inferred that, There is low level relationship between the achievement of the Experimental Group which is exposed to the developed peer tutoring technique and the attitude towards English as a second language.

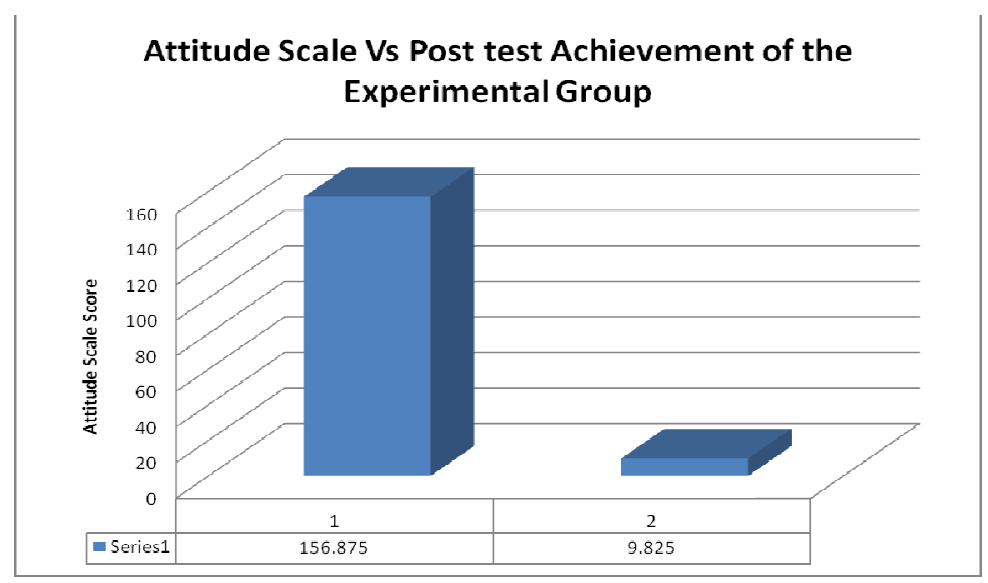

Figure 3

\section{METHODOLOGY}

The investigator has used experimental method. He has made use of 80(40+40) samples from two different Higher Secondary Schools in Erode District.

\section{Sample of the study}

For the presence of the study random sampling is used.

\section{Tools Used in the Study}

The both investigator along with the research supervisor has developed an achievement test paper and scoring key, gauge the achievement in the write perspective for 40 marks covering new test items. 
$\mathrm{He}$ is also developed his attitude scale attitude towards English as Second Language to the correlate the post achievement of the students. who are expose to the evolved peer tutoring technique for the subject in general science through English as the medium of the instruction at High school level.

\section{Administration of Pre-Test and Post-Test Achievement of the Two Groups}

Validity and reliability are established. Two groups are matched before the exposure of the technique Post Test was conducted.

\section{Statistical Technique Adopted}

- Mean and standard deviation

- $\quad$-test

- $\quad$ product movement correlation

\section{DATA ANALYSES AND INTERPRETATION}

Testing of hypothesis are carried out with help of the tables and graphical representations and the corresponding interpretation are recorded.

\section{Major Findings}

Negligible relationship between the achievement and attitude towards the English as the Second language as Medium of Instruction.

\section{LIMITATION OF THE STUDY}

- It is restricted only to the high school students

- $\quad$ English medium students are taken into account.

- Only Erode district two schools is taken up for the study.

\section{Educational Implications}

Men can do what machine can't do : machine can do men can't do. Peer tutoring is well proven and established technique which is being used across the ages. The one to one technique could work faster, cleaner and stronger. If the Peer tutoring is properly planned and implemented it will be successful programme. It is not expensive it can be utilized at any time at any place for any student from primary to university level. This technique can be also adopted to Inclusive Education Especially for differently abled students.

\section{CONCLUSIONS}

The present study has revealed that Peer tutoring Technique could augment remarkable achievement. Pertating to the subject General Science, of the student studying in High School level through General Science as English as a Medium of Instruction. 


\section{REFERENCES}

1. Program on reading skill acquisition for two-way bilingual first grade class room. Hearing Disability Quarterly. 62-2007

2. $\quad$ Fulk, King class wide Peer tutoring at work. Teaching Exceptional children 2001

3. Harper, Maheady, Peer - mediated teaching and students with learning disabilities. Intervention in school and clinic 2007

4. Spencer, Peer tutoring and students with emotional on behavioral disorders : A review of the literature Behavioral Disorders, 2006

5. Punzalan, D., \& Marie, E. (2018). Study Skills and Science Academic Performance of the Conditional Cash Transfer Program ('Pantawid Pamilyang Pilipino Program') Junior High School Beneficiaries in Zambales, Philippines. International Journal of Humanities and Social Sciences (IJHSS) ISSN (P).

6. Sutherland, snyder "Effects of reciprocal Peer tutoring and self graphing on reading fluency and classroom behavior of middle school students with emotional or behavioral disorders. Journal of Emotional and Behavioral Disorders 2007.

7. Vasquez, Slocum, "Evaluation of synchronous online tutoring for students at risk of reading failure. Exceptional children." 